\title{
En kvinne i 70-årene med dekompensert hjertesvikt under operasjon
}

\author{
Ved generell anestesi kan eldre pasienter med symptomgivende hjerte- \\ svikt være en utfordring. Akutte hemodynamiske forandringer kan \\ inntreffe. En lite brukt behandlingsmetode ble løsningen denne gang.
}

\section{Jostein Rødseth Brede}

jostein.rodseth.brede@stolav.no Klinikk for anestesi og intensivmedisin

St. Olavs hospital

> Se lederartikkel side 1336
En kvinne i 70-årene ble innlagt til elektiv laparotomi ved gynekologisk avdeling grunnet en oppfylning $i$ bekkenet. Hun hadde kjent diabetes mellitus type 2, var tidligere stentbehandlet for et hjerteinfarkt og hadde hjertesvikt med uttalt pulmonal hypertensjon. En måned før operasjon var hun innlagt på lokalsykehus med forverring av hjertesvikten. Røntgen thorax viste da en forstørret hjertekontur og forandringer som ved stuvning, og ekkokardiografi viste en ikkedilatert, hyperkontraktil venstre ventrikkel. Høyre ventrikkel var hypertrofisk med en liten trikuspidalinsuffisiens. Systolisk pulmonaltrykk ble målt til $85 \mathrm{~mm} \mathrm{Hg}$ lnormalt 15-28 $\mathrm{mm} \mathrm{Hg}$ ). Hjertesviktbehandlingen ble optimalisert medikamentelt, og hun ble utskrevet til hjemmet $i$ velbefinnende etter få dager. Av medikamenter brukte hun isosorbidmononitrat, enalapril, furosemid og spironolakton.

Pasienter med hjertesykdom er mer utsatt for peroperative kardiovaskulære problemer enn hjertefriske og har signifikant høyere 30-dagers mortalitet etter operasjon (1). Ved rutinemessig preoperativt tilsyn noen dager før den planlagte operasjonen følte kvinnen seg som normalt. På grunn av dette, den helt klare operasjonsindikasjonen samt nylig innleggelse på lokalsykehus der hjertesviktbehandlingen ble optimalisert, ble hun klarert for kirurgi.

Hjertesviktpasienter står gjerne på flere ulike typer medikamenter, hvor enkelte typer bør unngås på operasjonsdagen eller nulles et par dager i forkant. Typisk vil man beholde/ starte med betablokkere og statiner før operasjon, mens man må individuelt vurdere kontinuering av antihypertensiver av typen ACE-hemmere, angiotensin II-blokkere og kalsiumantagonister (2). På grunn av hennes uttalte hjertesvikt ble alle disse medikamentene kontinuert operasjonsdagen.

Pasienten hadde taledyspné og vansker med å ligge flatt på operasjonsbordet. Man la torakal epidural, arteriekran og sentralt venekateter og startet støtte av sirkulasjon med noradrenalin før innledning av narkosen. Det ble gitt en vanlig narkoseinnledning med
0,2 mg fentanyl, $250 \mathrm{mg}$ tiopental og $8 \mathrm{mg}$ vekuronium.

Generell anestesi gir sympatikusblokade med perifer vasodilatasjon og påfølgende blodtrykksfall. En vanlig brukt vasopressor, f.eks. noradrenalin, kan oppveie noe for dette. Pasienten fikk også epidural analgesi med lokalanestetika og opioider, som gir god smertelindring postoperativt. Epidural analgesi benyttes ofte også peroperativt for å redusere kirurgisk stress og gir mulighet til å bruke mindre anestesimidler.

Under operasjonen var oksygentilførselen over $60 \%$ for å unngå hypoksemi, og dette ga en arteriell oksygenmetning over $90 \%$. Ventilasjonen ble kontrollert ved kapnografi og blodgasser for å unngå hyperkapni. Noradrenalininfusjon ble gitt $i$ en moderat dose likke høyere enn 0,12 $\mathrm{gg} / \mathrm{kg} / \mathrm{min}$ ), noe som ga et systolisk blodtrykk pà over $100 \mathrm{~mm} \mathrm{Hg}$. Peroperativt ble det gitt intravenøs væskebehandling som forventet ved stor abdominalkirurgi, i underkant av $2000 \mathrm{ml}$ Ringeracetat. Ute $i$ det kirurgiske forløpet ble pasienten lagt $i$ lett Trendelenburgs leie for å muliggjøre kirurgi og hun fikk da plutselig oksygenmetningsfall ned mot $80 \%$. Anestesilege ble tilkalt, oksygentilførsel ble økt til $100 \%$ og det ble økt på ventilatortrykkene, delvis også ventilert for hånd. Hun fikk imidlertid ytterligere oksygenmetningsfall ned mot $70 \%$. Korrekt tubeleie ble verifisert ved auskultasjon og viste bilateralt lik lungelyd. Pasienten hadde da uttalte obstruktive lungefunn, men ingen auskultasjonsfunn forenlig med lungeødem. Det var ingen tydelige STforandringer på hjerterytmemonitoreringen eller endret hjerterytme. Det var heller ingen ukontrollert kirurgisk blødning. Pasienten var stasepreget $i$ hode og hals, med struttende halsvener og var kald og klam i huden. Blodtrykket falt noe og noradrenalindosen ble økt.

Ved peroperativ hypoksi må tubeleie verifiseres auskultatorisk og/eller bronkoskopisk. Ved bevegelse av tuben eller ved Trendelenburgs leie (sjokkleie) kan tuben skli forbi carina inn i en hovedbronkie, oftest høyre, og gi enlungeventilasjon. Dette gir lavere 


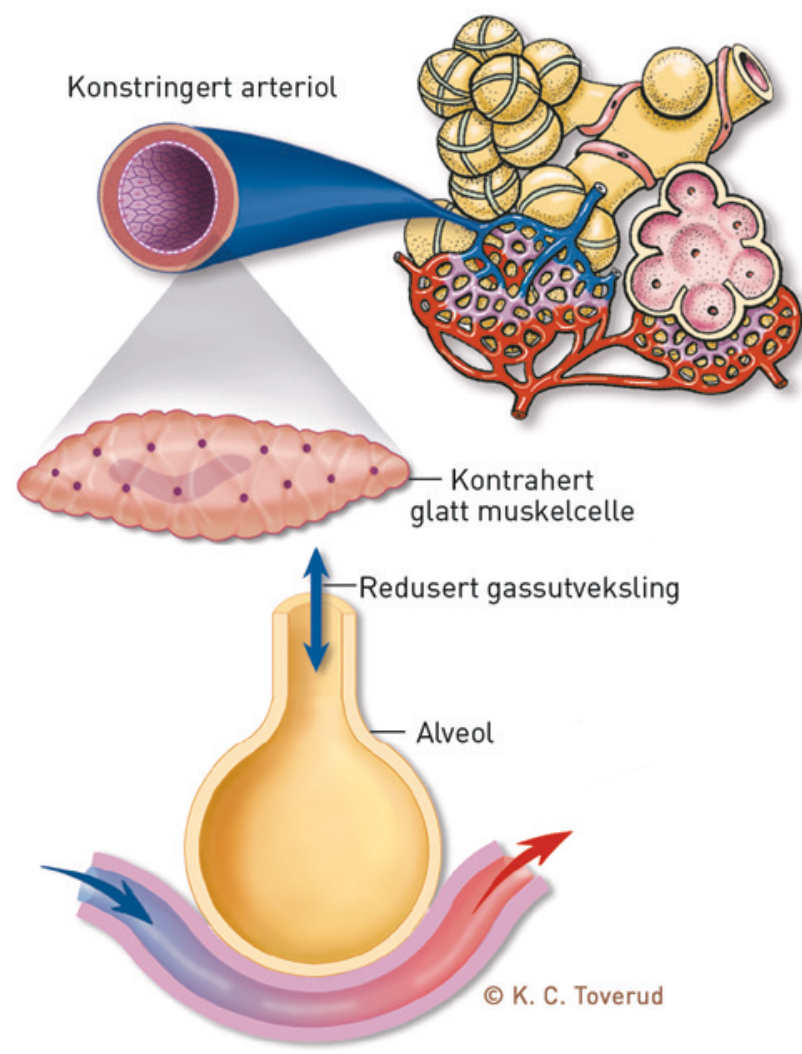

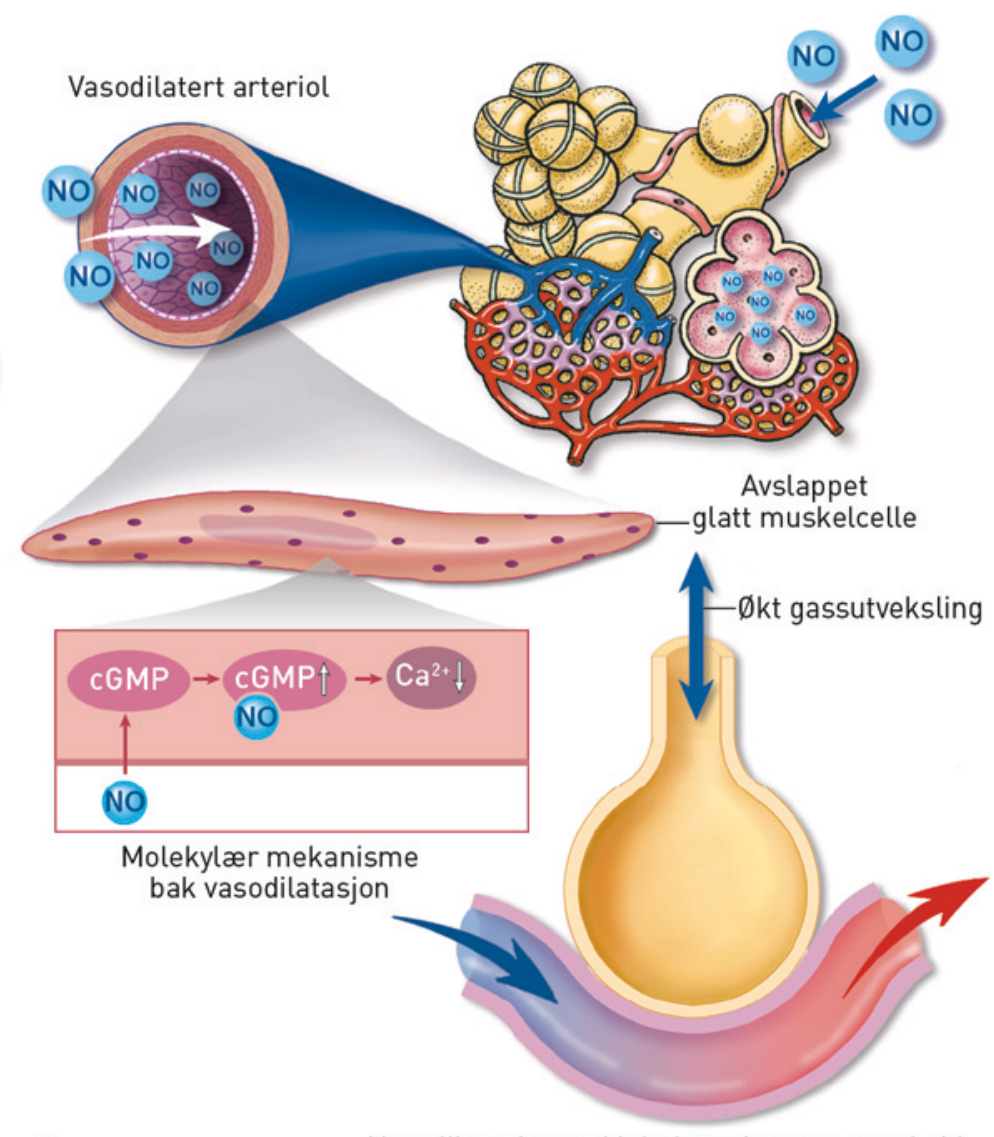

b

Vasodilatasjon ved inhalert nitrogenmonoksid

Figur 1 Virkning av inhalert nitrogenmonoksid (iNO) ved hypoksisk vasokonstriksjon. al hypoksisk vasokonstriksjon, b) vasodilatasjon ved iNO

minuttventilasjon, hypoksi og behov for høyere respiratortrykk. Kardial iskemi eller arytmi kan også gi sirkulatoriske forandringer. Verken galt tubeleie eller iskemi/arytmi kunne forklare pasientens fallende oksygenmetningsnivå.

En mer erfaren anestesiolog ble tilkalt og det ble gitt intravenøst $20 \mathrm{mg}$ furosemid og $300 \mathrm{mg}$ aminofyllin, uten særlig respons. Akutt lungeemboli ble vurdert, men man mistenkte akutt dekompensert høyresidig hjertesvikt som sannsynlig årsak, dette grunnet allerede kjent pulmonal hypertensjon. Det ble deretter raskt satt i gang behandling med inhalert nitrogenmonoksid (iNO) og i løpet av minutter bedret oksygeneringen seg betydelig. Luftveistrykkene og oksygentilførselen kunne reduseres, og man fikk reetablert perifer sirkulasjon og redusert behov for vasopressor. Operatørene var informert om forløpet underveis og operasjonen ble gjennomført som planlagt, uten nevneverdig forsinkelse. Pasienten ble holdt sedert og flyttet til intensivavdelingen for kontrollert nedtrapping av inhalert NO. Transtorakal ekkokardiografi viste normal venstre ventrikkel-funksjon, lett dilatert høyre ventrikkel med redusert langakseforkortning og systolisk pulmonaltrykk estimert til $75 \mathrm{~mm} \mathrm{Hg}$, altså en relativt lik situasjon som preoperativt. Etter nedtrapping av NO-behandling ble pasienten ekstubert ukomplisert samme kveld.

\section{Diskusjon}

Denne pasienten var utsatt for å få en akutt høyresidig hjertesvikt pga. sin alvorlige pulmonale hypertensjon. Ved preoperativ anestesivurdering gjennomgår man bl.a. medisinske opplysninger, funksjonsnivå, aktuell medisinering og tidligere anestesierfaringer. Operasjonsindikasjon og kirurgiens art må også tas med i vurderingen. Kvinnen hadde nylig vært innlagt ved lokalsykehus der det var gjort fornuftige medikamentelle tiltak, som ifølge henne selv hadde hatt god effekt. Videre var operasjonsindikasjonen helt klar. Derfor ble operasjonen startet som planlagt. Imidlertid var monitoreringen relativt beskjeden og årsaksmekanismene derfor usikre. Sett retrospektivt kan nok peroperativ bruk av pulmonalarteriekateter for måling av hjerteminuttvolum, systemvaskulær og pulmonal vasku- lær motstand eller ekkokardiografi ha hjulpet både diagnostisk og gitt mer presis tilbakemelding på behandlingseffekt.

Under operasjon kan hypoksi, hyperkapni og kirurgisk stress bidra til pulmonal vasokonstriksjon og dermed økt pulmonal vaskulær motstand. Dette gir økt høyresidig arterietrykk, som kan gi dilatasjon av høyre ventrikkel og høyresidig hjertesvikt. Tilstanden kan progrediere inn $\mathrm{i}$ en ond sirkel der ytterligere forverring gir enda mer økt pulmonal vaskulær motstand og ytterligere dilatasjon av høyre ventrikkel. Til slutt svikter høyre ventrikkel fullstendig og pasienten får en uttalt sirkulasjonskollaps. Ventriklene er avhengige av hverandres funksjon (ventricular interdependence). Opptil 20-40\% av høyre ventrikkels systoliske trykk og volumstrøm genereres av venstre ventrikkels kontraksjon (3). Her var det ikke holdepunkt for å si at venstre ventrikkel i utgangspunktet kontraherte for dårlig. Imidlertid er fylningen av venstre ventrikkel avhengig av at høyre ventrikkel får pumpet videre det volumet den får tilført. Derfor falt blodtrykket sekundært til den sviktende høyre ventrikkel-funksjonen.

En «for lett» anestesi ville kunne gi økt 
pulmonal vaskulær motstand, men anestesien ble på tidspunktet før hendelsen oppfattet å være dyp nok. Enlungeventilasjon ble utelukket auskultatorisk, da pasienten hadde sidelike respirasjonslyder. Akutt lungeeboli ble også vurdert, men dette var mindre sannsynlig. Trendelenburgs leie benyttes ofte peroperativt, både for å lette kirurgisk tilgang, men også for å heve blodtrykket ved å øke venøs tilbakestrøm, og dermed fyllingstrykk, til hjertet. I dette tilfellet kan man imidlertid tenke seg at Trendelenburgs leie ga økt volumbelastning på en allerede sviktende høyre ventrikkel, og at det derfor ikke var gunstig. Således kan man tenke seg at å legge pasienten tilbake i flatt leie ville avhjulpet høyre ventrikkel ved å redusere volumbelastningen. Dette ble ikke forsøkt.

I behandlingen av akutt høyresidig hjertesvikt er det vesentlig å redusere arterietrykket i høyre ventrikkel. Dette innebærer bl.a. å øke oksygenering, redusere respiratorisk eller metabolsk acidose eller å dilatere lungekarsengen, f.eks. ved bruk av inhalert NO (4). NO het opprinnelig endotelderivert relakserende faktor og er en naturlig vasodilator som bidrar til å regulere vaskulær motstand $(5,6)$. Det produseres i endotelcellene fra L-arginin ved hjelp av enzymet endotelial nitrogenoksidsyntase (eNOS). Etter inhalering krysser NO raskt alveole-kapillær-barrieren og inn i glatt muskel, hvor det aktiverer guanylat cyclase, et enzym som konverterer guanosintrifosfat (GTP) til syklisk guanosinmonofosfat (cGMP). NO gir således økt mengde cGMP, som reduserer intracellulært kalsium og gir relaksasjon av glatt muskel. Når den administreres som inhalasjon, gir den selektiv dilatasjon av pulmonal vaskulatur (7) (fig 1).

Inhalert NO elimineres raskt ved å bindes til hemoglobin i lungekapillærene og har derfor liten systemisk påvirkning (8). En vanlig startdose er 15-20 ppm, og systemet kan kobles rett på pasientsirkelen på en ventilator.

Pasientens oksygenering bestemmes av intrapulmonal fordeling av ventilasjon og blodstrøm, den såkalte ventilasjon/perfusjons-ratioen (V/Q-ratio). Normalt vil lav oksygentensjon gi vasokonstriksjon i kar- sengen i de hypoksiske områdene (hypoksisk vasokonstriksjon). Blodstrømmen blir dermed redistribuert til områder med bedre ventilasjon og høyere intraalveolært partialtrykk av oksygen. Inhalert NO bedrer denne mekanismen ved å øke blodstrømmen til godt ventilerte lungeområder. Dette er i kontrast til intravenøse vasodilatatorer, som gir dilatasjon i hele lungekarsengen, altså inklusive områder med ikke-ventilert lunge, og derfor øker intrapulmonal shunting og reduserer partialtrykket av oksygen i blodet $\left(\mathrm{PaO}_{2}\right)(9)$.

Plutselig seponering av inhalert NO kan gi en tilbakevendende pulmonal hypertensjon, med forverring av V/Q-ratio, hypoksemi og sirkulasjonskollaps. Mekanismene bak er noe usikre, men kan bl.a. involvere nedregulering av endogent produsert $\mathrm{NO}$. En kontrollert reduksjon av inhalert NO anbefales derfor $(10,11)$. Dette ble gjort med hell hos vår pasient.

Behandling med inhalert NO gjøres i en viss utstrekning hos både voksne pasienter og nyfødte på intensivavdelinger. Det er imidlertid svært uvanlig å bruke inhalert NO peroperativt. På vårt sykehus finnes det ingen retningslinje for slik peroperativ bruk, og ved litteratursøk finner man heller ikke god dokumentasjon. Således må dette kunne klassifiseres som eksperimentell behandling. Det er etiske betenkeligheter med å bruke ikke-dokumentert terapi på pasienter som ikke har samtykket til dette. Men når pasienten blir akutt kritisk syk under narkose, må man noen ganger benytte seg av ukonvensjonelle og dårlig dokumenterte tiltak. Dette er et dilemma anestesiologer ikke sjelden står overfor.

\section{Konklusjon}

Vår pasient fikk en dramatisk forbedring i hemodynamisk og respiratorisk funksjon etter kun kort tids bruk av inhalert NO. Dette tyder på at inhalert NO kan være til god hjelp ved perioperativ akutt høyresidig hjertesvikt, for raskt å redusere pulmonal motstand. Kasuistikken illustrerer også at kunnskap om patofysiologi kan være til hjelp for å løse vanskelige kliniske situasjoner.

\section{Jostein Rødseth Brede (f. 1981)}

er lege i spesialisering i anestesiologi.

Forfatter har fylt ut ICMJE-skjemaet og oppgir ingen interessekonflikter.

Pasienten har gitt samtykke til at artikkelen blir publisert.

Takk til Ole Kristian Rolfseng og Pål Klepstad for hjelp til utformingen av manuskriptet.

Litteratur

1. Sellevold OFM, Stenseth R. Ikke-kardial kirurgi hos hjertesyke pasienter. Tidsskr Nor Legeforen 2010; 130: 623-7.

2. Ræder J, Støen R. Dosering av faste legemidler før elektive operasjoner. Tidsskr Nor Legeforen 2012; 132: $304-6$

3. Santamore WP, Dell'Italia LJ. Ventricular interdependence: significant left ventricular contributions to right ventricular systolic function. Prog Cardiovasc Dis 1998; 40: 289-308

4. Lahm T, McCaslin CA, Wozniak TC et al. Medical and surgical treatment of acute right ventricular failure. J Am Coll Cardiol 2010: 56: 1435-46.

5. Palmer RM, Ferrige AG, Moncada S. Nitric oxide release accounts for the biological activity of endothelium-derived relaxing factor. Nature 1987 327: $524-6$

6. Pepke-Zaba J, Higenbottam TW, Dinh-Xuan AT et al. Inhaled nitric oxide as a cause of selective pulmonary vasodilatation in pulmonary hypertension. Lancet 1991; 338: 1173-4.

7. Archer SL, Huang JM, Hampl V et al. Nitric oxide and CGMP cause vasorelaxation by activation of a charybdotoxin-sensitive $\mathrm{K}$ channel by cGMPdependent protein kinase. Proc Natl Acad Sci U S A 1994: 91: 7583-7.

8. Rimar S, Gillis CN. Selective pulmonary vasodilation by inhaled nitric oxide is due to hemoglobin inactivation. Circulation 1993; 88: 2884-7

9. Ichinose F, Roberts JD Jr, Zapol WM. Inhaled nitric oxide: a selective pulmonary vasodilator: current uses and therapeutic potential. Circulation 2004: 109: 3106-11

10. Pearl JM, Nelson DP, Raake JL et al. Inhaled nitric oxide increases endothelin-1 levels: a potential cause of rebound pulmonary hypertension. Crit Care Med 2002; 30: 89-93.

11. Christenson J, Lavoie A, O'Connor M et al. The incidence and pathogenesis of cardiopulmonary deterioration after abrupt withdrawal of inhaled nitric oxide. Am J Respir Crit Care Med 2000; 161 1443-9.

Mottatt 9.1. 2015, første revisjon innsendt 9.4 2015, godkjent 22.5. 2015. Redaktør: Lise Mørkved Helsingen. 